\title{
INDUSTRIAL DEVELOPMENT BONDS: REVIEWING THE EVIDENCE IN THE NORFOLK-VIRGINIA BEACH SMSA*
}

\author{
Matthew R. Marlin*
}

\section{Introduction}

The growing volume of tax-exempt Industrial Development Bonds (IDBs) over the past few years has been accompanied by a growing controversy over the purposes and results of their use. ${ }^{1}$ As Pascarella and Raymond (1982) observe, a part of this controversy stems from the failure of Congress to adequately define the intended objectives of IDBs. The 1981 Congressional Budget Office report Small Issue Industrial Revenue Bonds identified three goals that Congress may have attempted to achieve when it considered IDB legislation:

1) To provide a general subsidy to stimulate investment;

2) To provide assistance to small and/or high-risk firms that have difficulty obtaining conventional financing; or,

3) To stimulate economic development in economically distressed areas. (CBO, p. 54.)

Subsequent to the CBO study and extensive committee hearings, Congress restricted the use of IDB financing under the provisions of the Tax Equity and Fiscal Responsibility Act of 1982 (TEFRA) which took effect in January and June, 1983. Data reflecting the impacts of this legislation are not yet available; however, historical trends of IDB use can form the basis for projecting the probable effects of the new TEFRA restrictions.

The purpose of the present study is to determine whether or not the use of IDBs in the Norfolk-Virginia Beach, Virginia, SMSA has been consistent with the implied Congressional objectives outlined above. In addition, the study evaluates the past distribution of IDBs within the region in order to estimate what effects the TEFRA legislation may have on future use. ${ }^{2}$

\section{Industrial Development Bonds as a General Subsidy}

Industrial Development Bonds were not originally intended to be a general investment subsidy. Their original intent was to be a locational subsidy designed to attract firms to capital-poor regions in a few Southern states. Although first used in 1936, IDBs did not gain widespread popularity until the mid1960s. By 196840 states had passed legislation permitting IDBs, and their annual volume had grown to $\$ 1.6$ billion with an average size of $\$ 8.9$ million (Apilado, p. 21 ). Concerned not only by their growing volume but also by their extensive use by major corporations for multi-million dollar projects, Congress restricted IDB use under the provisions of the Tax Revenue and Expenditure Control Act of 1968.

Beginning in 1969, unrestricted use of IDBs was limited to bonds with a face value of $\$ 1$ million or less. IDBs could exceed this amount provided that the total capital investment of the receiving firm in 
the same political subdivision was less than $\$ 5$ million for a period extending from three years before the bond issue to three years after. (The investment limit was raised to $\$ 10$ million in 1979 .) Exemptions were provided for certain quasi-public projects such as civic centers, pollution control equipment, docks and wharves, and industrial parks. However, federal and Virginia statutes restricted neither the projects for which IDBs could be used, the volume issued for an individual firm, nor the volume which could be issued by a given community. ${ }^{3}$

Although the near equal availability of IDBs in most states rendered them ineffective as a locational influence (CBO, p. 48), local governments pursuing economic development programs still found IDBs to be an attractive policy tool for stimulating local investment. As it often has been pointed out (Laufenberg, p. 140), local authorities experience no direct costs when issuing IDBs. Reduced federal revenues and higher municipal bond yields are borne by the nation as a whole, and the legal and administrative costs of the bond issue are passed on to the firm receiving the IDB. Consequently, local development agencies were able to provide low interest financing to firms (for projects costing less than $\$ 5$ million) without having to incur any costs. From the local perspective, even if IDBs were ineffective in promoting economic growth by influencing inter-regional capital flows, they remained an attractive tool for aiding economic development by lowering the cost of capital for local firms. Used in this manner IDBs function as a general investment subsidy.

The evolution of IDBs from an inter-regional location determinant to a general investment subsidy can be documented by analyzing the manner and extent to which they have been used in the NorfolkVirginia Beach SMSA. The remainder of this section will demonstrate that IDBs have been used to finance a growing share of local investment, that they have been used primarily by local firms, and that their use parallels that of other general investment subsidies.

The volume of IDB use in the SMSA from 1973 through 1982 is shown in Table I. The slow growth in issues through 1978 can be attributed to two factors. First, the issue and administration of an IDB is a cumbersome process involving the establishment of local development authorities and numerous other legal requirements. Until the issue and administrative procedures could be standardized and streamlined, IDBs were a time consuming and costly endeavor. Second, adding legal and administrative costs to the IDB effectively raised the cost of tax-exempt financing to private businesses. Unless the spread between tax-exempt and conventional taxable loan rates was significant, conventional financing remained the less costly alternative.

By 1979, industrial development agencies in the SMSA were securely established; and the process of issuing IDBs had become standardized and less costly. An additional factor is that the Norfolk-Virginia Beach SMSA is comprised of five cities each independently pursuing its own economic growth. In a situation similar to the "prisoner's dilemma," each city felt required to offer IDBs freely as long as the other cities made them available. More importantly, in 1979 the nominal level of interest rates began an upward climb to record levels; and IDBs, therefore, became a more attractive financing alternative to businesses. The reduced costs, ready availability, and widening interest rate spreads were perhaps the most important factors contributing to the IDB explosion in 1979.

The increased popularity of IDBs in the region can be seen by examining the fourth column of Table I. As indicated, by 1981 over 60 percent of the applicable construction in the SMSA was financed with IDBs. Non-IDB construction consisted primarily of projects which exceeded the $\$ 10$ million cap imposed by Congress and projects which were too small to overcome the high administrative cost of IDB issues.

The high administrative costs associated with IDBs have tended to bias their use away from small projects. This is a serious problem if the program is meant to be a general subsidy. At present, it is estimated that $\$ 150,000$ is the minimum size IDB necessary to make tax-exempt financing less costly than conventional bank loans. The size distribution of IDBs issued in the SMSA is presented in Table II. Of the 46 projects costing less than $\$ 150,000$, fourteen were actually financed with a single taxexempt loan procured by a local redevelopment agency. However, legal and administrative considerations have limited this practice in the SMSA. Another sixteen were supplements to prior IDBs necessitated by cost overruns.

Within the applicable cost range $(\$ 150,000-\$ 10$ million), IDB use in the SMSA has been dominated by local firms; and the primary market for the bonds has been local commercial banks. Eighty-two percent of the region's IDBs were obtained by local firms and individuals to expand regional operations, 


\section{TABLE I}

\section{IDB Use in Norfolk-Virginia Beach SMSA}

(\$ in millions)

\begin{tabular}{|c|c|c|c|}
\hline Year & Issues & Dollar Volume & Percent of Building Permits ${ }^{1,2}$ \\
\hline$\overline{1973}$ & 11 & $\$ 13.2$ & $15.1 \%$ \\
\hline 1974 & 22 & 15.0 & 10.4 \\
\hline 1975 & 4 & 24.0 & 39.0 \\
\hline 1976 & 11 & 12.7 & 12.4 \\
\hline 1977 & 26 & 43.7 & 17.1 \\
\hline 1978 & 26 & 41.5 & 28.3 \\
\hline 1979 & 80 & 128.1 & 48.7 \\
\hline 1980 & 92 & 69.9 & $29.8^{3}$ \\
\hline 1981 & 108 & 121.2 & 62.3 \\
\hline 1982 & 144 & 122.4 & 63.8 \\
\hline Totals & 524 & $\$ 591.7$ & $\overline{37.0 \%}$ \\
\hline
\end{tabular}

1Source: Builders and Contractors Exchange, Norfolk, Virginia

${ }^{2}$ Applicable building permit data were available only for Norfolk, Virginia Beach and Chesapeake. Therefore, only IDBs issued in these cities were included. Further adjustments were made to allow for IDBs used to purchase equipment rather than build structures.

3Despite a general investment slowdown caused by the recession in 1980 , building permits for two atypically large construction projects were issued in this year. Each project exceeded $\$ 10$ million and could not use IDB financing, thereby resulting in the indicated fall in the percentage of IDB financed projects.

to make an intra-regional move, or to start new enterprises. The remainder were used by multi-state, national, or international firms to open local franchise or branch operations. On the purchasing side, the buyers of 505 IDBs could be identified. Of these, 81 percent were local commercial banks and another 6 percent were non-local banks. The remainder were purchased by insurance companies, individuals, or were sold as public issues. ${ }^{4}$

The above evidence supports Laufenberg's contention that IDBs closely resemble bank loans (p. 140). In the Norfolk-Virginia Beach SMSA, IDB applicants usually are required to procure and negotiate their loans prior to the bond issue; thus, the bond marketing itself is merely a formality. If a bank is to be the bond purchaser, the industrial development authorities, in effect, simply "rubber-stamp" conventional bank loans in order to provide tax-exempt financing to local firms and tax-exempt income to local banks. In Laufenberg's words, ". . . such financing functions simply as a conduit to the tax-exempt market" (p. 139).

General investment subsidies such as the investment tax credit and accelerated depreciation are used more by growing firms and industries than declining ones (Luger, p. 201; Kopke and Syron, p. 22). Growing businesses undertake more investment projects and generate greater profits and therefore have more opportunity to avail themselves of the subsidies. Analogously, if IDBs also function as a general subsidy it should be expected that the growing segments of the local economy would use them more frequently since they are undertaking more investment projects. The evidence from the Norfolk-Virginia Beach SMSA supports this contention.

Table III presents the distribution of IDB using firms by Standard Industrial Classification. The fastest growing sector of the local economy, Services, used exactly one-third of the region's IDBs. The second and third fastest growing sectors, Finance/Insurance/Real Estate and Wholesale Trade used another 19 percent. ${ }^{5}$ The relatively intense use by the declining (in employment share) manufacturing sectors was due to the capital-intensive nature of industry as well as to the local concentration of maritime industries which could avail themselves of the docks and wharves exemption. Although the original intent of the program was that investment would be a function of IDB availability, it appears that IDB volume has instead become a function of the level of investment. ${ }^{6}$ 


\section{TABLE II}

The Size Distribution of IDB Issues

In Southeast Virginia: 1973-82

Dollar Range

$\$ 0-150,000$

$\$ 150,001-250,000$

$\$ 250,001-500,000$

$\$ 500,001-1,000,000$

$\$ 1,000,001-5,000,000$

$\$ 5,000,001-10,000,000$

Over $\$ 10,000,000^{1}$
Number of IDBs

46

78

144

132

111

7

6
Total Dollar Volume

(\$millions)

$\$ 4.6$

16.8

55.4

101.6

254.1

58.0

101.4

1The six projects greater than $\$ 10$ million were allowed under the exemptions to the 1968 Tax Act. They include three hospital expansions, two docks and wharves projects, and a waterfront retirement home operated by a non-profit organization.

In summary, the desire of local authorities to expand their tax bases and the lack of cost or legal restrictions on IDB use have led to their evolution into a general investment subsidy in the NorfolkVirginia Beach SMSA. The only apparent bias in the subsidy is its cost ineffectiveness for projects less than $\$ 150,000$. Similar to other investment subsidies, IDBs have been used most by growing firms and industries.

\section{IDBs and Small or High-Risk Firms}

To the extent that small projects are associated with small firms, such firms are limited in their use of IDBs. As noted above, the administrative costs associated with issuing municipal bonds require that IDBs be of sufficient size to overcome the initial costs and make the interest subsidy economically practical. Although employment figures per firm were not available for all firms in the region, a sample

\section{TABLE III}

\section{IDB Use By Industry}

Services

Durable Foods

Manufacturing

Non-Durable

Manufacturing

Finance, Insurance

\& Real Estate

Retail Trade

Wholesale Trade

Transportation \&

Public Utilities

Construction

Agriculture \&

Mining

Social Institutions

Totals $\frac{\text { Number }}{140}$

66

65

64

76

73

28

8

2

2

524
Number

$\$ 197.2$

104.3

86.2

61.8

60.7

49.1

27.4

3.6

1.2

0.3

$\$ 591.8$
Percentage of

Dollar Volume $33.3 \%$

17.6

14.6

10.5

10.3

8.3

4.6

0.6

0.2

$-$

$100.0 \%$ 
of 540 manufacturing firms with employment data was available from the Greater Hampton Roads Organization. These firms were analyzed by employment level and IDB use, and the results are shown in Table IV.

As indicated in the Table, none of the manufacturing firms in the sample with employment of ten or less used IDBs during the 1973-82 period. Of the 20 firms in the 11-25 employment range, 7 were subsidiaries of national or international firms and, therefore, cannot realistically be considered "small" firms. The percentage of firms in each size category using IDBs increased up to the largest category.

Contrary to what Congress may have intended, the evidence indicates that IDBs have been obtained more frequently by larger firms than by smaller ones. The provisions of the 1968 Tax Act limited IDB use to $\$ 5$ million ( $\$ 10$ million) per firm, per political subdivision, but did not limit the total volume which could be used by a given business. Although this constraint prohibited large firms from using the subsidy to finance major investment projects in one locality, it did not prohibit them from using IDBs to finance a large number of geographically dispersed facilities such as warehouses, offices, and franchised or "chain" operations. For example, local IDBs were used by Mobil Oil to construct a storage/distribution facility for oil products; Borden's built a dock storage facility for a lading subsidiary; Standards Brands constructed a warehouse for its Planter's Nuts division; and General Mills and Ralston Purina used IDBs to open new facilities for their "chain" restaurants (Daryl's and Carlos Murphy's, respectively).

The often cited use of IDBs by major commercial enterprises such as K-Mart, McDonalds, and Eckerd Drug Stores is not surprising given the form of the restrictions imposed by the 1968 Act. These firms expend capital for a large number of dispersed market-oriented facilities, each costing less than the mandated per-city limit. IDBs, therefore, are ideally suited for their use. In the Norfolk-Virginia Beach SMSA, 18 percent of the issues and 28 percent of the IDB dollar volume financed branch or franchise operations for multi-state, national, or international firms.

The availability of IDBs for such dispersed projects has led to the introduction of "umbrella IDBs." Umbrella IDBs are publicly issued and sold in national markets for an amount in excess of $\$ 10$ million. The proceeds are used to finance a number of geographically dispersed projects. In this manner, major corporations can take advantage of the lower interest rates and scale economies which accompany large public issues.

Intra-regional firms in a multi-city SMSA also may take advantage of the per-city restrictions. Heavy investment in one city does not preclude IDB financing of warehouse or retail outlets on the other side of a city line. The umbrella bond option, however, is not generally available for such firms, and this reinforces the bias of the subsidy towards larger corporations.

In order to assist high-risk firms, regardless of size, to obtain financing, Industrial Development Bonds would need to close a credit gap by providing additional loan security. This has not been the case. With very few exceptions, IDBs are revenue bonds which require the receiving firm to guarantee the bonds. As indicated in the previous section, the majority of IDBs were purchased by professional lending institutions; and these institutions typically require the borrower to provide similar loan collateral regardless of the taxable status of the loan. As mentioned above, the IDB receiving firm itself must procure financing prior to the bond issue. New or high-risk firms, therefore, have little better access to

\section{TABLE IV}

\section{IDB Use by Size of Firm}

\begin{tabular}{|c|c|c|c|}
\hline Employment & Number of Firms & Firms Using IDBs* & Using IDBs \\
\hline $1-10$ & 208 & 0 & $0 \%$ \\
\hline $11-25$ & 135 & 20 & 14.8 \\
\hline $26-50$ & 67 & 12 & 17.9 \\
\hline $51-100$ & 63 & 14 & 22.2 \\
\hline $101-500$ & 57 & 26 & 45.6 \\
\hline Over 500 & 10 & 4 & 40.0 \\
\hline
\end{tabular}


tax-exempt financing than they do to conventional bank loans. ${ }^{7}$ This contention is supported by the evidence in the Norfolk-Virginia Beach SMSA.

About $\$ 58$ million (9.7 percent) of the region's IDBs were used by firms which could be identified as "new." However, in each instance, the recipient firm was a newly formed partnership or corporation comprised of individuals with existing business interests in the region. About $\$ 40$ million of these IDBs were used by newly formed development companies to build office buildings or shopping centers. Although these newly organized firms are technically "new," it is doubtful that this is what Congress had in mind if they indeed intended IDBs to help close a credit gap for small or new businesses.

In summary, the use of IDBs has not led to a reallocation of capital to small firms in the NorfolkVirginia Beach SMSA because their high administrative costs place an effective minimum on the size of the projects which they can finance. To the contrary, the provisions of the 1968 Tax Act left the door open for large, geographically dispersed corporations to continue using IDBs to finance distribution centers and branch or franchise operations. Finally, because IDBs are almost exclusively revenue bonds, they close no credit gaps for truly new or high-risk enterprises.

\section{IDBs and Economically Distressed Areas}

There is no theoretical reason to believe that IDBs have directed capital toward economically distressed areas, in either an inter-regional or intra-regional context. ${ }^{8}$ In an inter-regional context, IDBs are equally available in 47 states (CBO, p. 70-71). Similar to other ubiquitous resources, they exert no locational pull towards any region. The same holds true within most regions. In the Norfolk-Virginia Beach SMSA, IDBs are as available in the rapidly growing suburban sections as they are in the "declining" central city.

Given the near universal availability of IDBs and the lack of limits on their issue by any region or city, it should be expected that growing regions would experience more IDB activity than depressed regions. During the past decade, national employment trends have been toward growth in marketoriented activities such as services and trade; and firms in these industries are more likely to expand or open branches in growing regions where the markets are. It would follow that growing regions would have more opportunity to use IDBs and hence would use them more than depressed regions. Local evidence supports this contention in both inter- and intra-regional contexts.

From an inter-regional perspective, the Norfolk-Virginia Beach SMSA experienced rapid growth during the past decade. From 1973 to 1981 population increased by 7.0 percent, and employment increased by almost 20 percent. ${ }^{9}$ During the recessionary period between 1980 and 1982, unemployment rates in the area averaged about 2 points less than the U.S. average; and the region historically enters recessions later and leaves them earlier than the nation as a whole. In short, the region is a growth area, and it should be expected that IDB use would have been heavier than the national average. The evidence shown in Table $\mathrm{V}$ supports this contention. ${ }^{10}$ Even allowing for extreme underestimation at the national level, the figures in Table V clearly indicate that IDB use in the Norfolk-Virginia Beach SMSA has been much higher than the national average, as would be expected in a growing region.

Although data regarding the intra-regional location of IDB-using firms are difficult to obtain, it appears that the intra-regional use of IDBs mirrors their inter-regional use: their ready availability in all parts of the SMSA negates any locational pull they may have. In the central-city portions of the SMSA, IDBs were used primarily by the ship repair industry and by developers renovating old buildings to provide modern office space. In suburban areas, IDBs were used to construct market-oriented facilities such as new office buildings, shopping centers, and retail outlets.

Rather than reallocating capital toward declining portions of the SMSA, IDBs have more commonly supported the flight of businesses to the suburbs. One hundred twenty-nine IDBs issued in the region were used by firms to move to new locations. Approximately 50 of these changes involved movements from central-city regions to new or expanding industrial parks at the inner-city periphery. Another 50 were used to move from inner-city locations to suburban sites in different cities within the region. Likewise, firms that used IDBs to expand existing businesses into new locations (intra-regional branches) showed a strong tendency toward outward expansion. All in all, over 76 percent of the firms using IDBs could be classified as "market oriented," and IDB use coincided with the general market decentralization trend which characterized most U.S. urban areas during this period. 


\section{TABLE V}

Per Capita IDB Comparisons

Norfolk-Virginia Beach and the U.S.

Year

1973

1974

1975

1976

1977

1978

1979

1980

1981

1982
Norfolk-Virginia Beach

$\$ 18$

20

32

17

56

53

162

88

150

150

\begin{tabular}{r} 
U.S.* \\
\hline$\$ 9$ \\
8 \\
12 \\
12 \\
30 \\
35 \\
44 \\
48 \\
58 \\
66
\end{tabular}

*Source: Federal Reserve Flow of Funds Accounts and Statistical Abstract of the United States

Because IDBs are equally available in nearly all localities, their use has tended to reinforce existing geographical trends in capital investment rather than reverse or redirect these trends. Analogous to the way that subsidies in general tend to benefit profitable and growing industries, IDBs also tend to benefit growing regions in both inter- and intra-regional contexts.

\section{IDBs and the TEFRA Restrictions}

Legislation included in TEFRA restricted the use of IDBs in three ways. First, administrative requirements were increased. These included reporting and registration requirements, as well as public hearings and approval by a body of publicly elected officials. These requirements will undoubtedly increase the administrative costs of IDB issues and further bias their use away from small firms and projects. ${ }^{11}$ Second, capital financed with IDBs will no longer be eligible for full accelerated depreciation allowances. The effect of this restriction on future IDB use is unclear and will require further study once data for 1983 and beyond are available. Limiting depreciation allowances, however, may limit the use of IDBs by highly profitable and growing firms which have greater tax liabilities than small or struggling firms.

The third TEFRA restriction was directed at what Congress considered to be the "abusive" use of IDBs to finance projects not considered to be in line with perceived public purpose. Section 103 of the Internal Revenue Code was amended to completely deny the use of tax-exempt IDBs for any of the following projects: golf courses, country clubs, massage parlors, raquet clubs, skating rinks, racetracks, and suntan and hot-tub facilities. In addition, IDBs cannot be used if more than 25 percent of the bond proceeds are used to finance restaurants, auto sales and service centers, or other recreational facilities not included in the above list. Table VI presents the past distribution of IDBs used to finance "abusive" projects.

As seen in the data presented in Table VI, the past use of IDBs in the Norfolk-Virginia Beach SMSA was dominated by "non-abusive" projects. Only .5 percent of past projects would have been totally prohibited by the TEFRA restrictions, and only 4.8 percent would have been "partially" prohibited.

The TEFRA restrictions are likely to have a slight negative impact on the ability of IDBs to attain the goals described at the outset of this study. Their use as a general subsidy has been further limited by decree to exclude certain types of projects, and the increased administrative requirements will likely increase their bias toward larger projects. No action was taken to stem their use by major corporations to open branch facilities throughout the nation, and none of the restrictions is designed to divert capital to depressed regions. 


\section{Conclusions}

The history of IDB use in the Norfolk-Virginia Beach SMSA has been partially consistent with only one of the Congressional goals outlined at the beginning of this study. First, although they have evolved into a very broad investment subsidy, their generality has been limited somewhat by high administrative costs which act to deny IDB financing for small projects, as well as by the intentional size restrictions included in the 1968 Tax Act. Their use for smaller projects would be enhanced if state and Federal laws were changed to allow direct tax-exempt loans (upon public approval) rather than the issue of municipal bonds for each IDB. In practice, industrial development authorities now serve as little more than a highcost conduit to tax-exempt markets; and eliminating their "middle-man" role would significantly reduce the cost of using IDBs and, thus, make them available for smaller projects.

IDBs essentially close no credit gaps for new or high-risk firms since they are predominantly revenue bonds which require the receiving firm to provide its own loan security. To the contrary, because size restrictions have been imposed only on a per-city basis, large established corporations have been able to freely use IDBs to construct dispersed facilities. Their access to the tax-exempt markets has been greater than small firms' contrary to the postulated goal. The use of general obligation IDBs would help close the credit gap for new businesses, but few localities are prepared to undertake the risk and public referenda necessary to pursue such a strategy. It is, therefore, doubtful that any simple adjustment to the existing IDB program can help achieve the goal of assisting new or struggling firms to obtain subsidized financing.

The third assumed Congressional goal, aiding distressed areas, is also apparently unreachable through the use of IDBs. Because they are available almost universally, they exert no locational pressures. Location decisions will continue to be guided by other factors; and if IDBs are available at the chosen site, they will probably be used. Restricting IDBs to enterprise zones, as has been proposed, will certainly

\section{Table VI}

\section{Past Projects in Southeast Virginia \\ Ineligible for IDB Financing Under the TEFRA Provisions}

Totally Prohibited:

Issues Amount $(\$ \mathrm{~m})$

Percent of Total IDBs

Golf Courses

Country Club

Massage Parlors

\begin{tabular}{lll}
1 & $\$ 0.9$ & $0.2 \%$ \\
0 & 0 & 0 \\
0 & 0 & 0 \\
2 & 1.4 & 0.2 \\
2 & 0.7 & 0.1 \\
0 & 0 & 0 \\
0 & 0 & 0 \\
0 & 0 & 0 \\
\hline 5 & $\$ 3.0$ & $0.5 \%$
\end{tabular}

Racquet Clubs

Skating Rinks

Racetracks

Suntan Facilities

Hot Tub Facilities

Total

1.6

Restaurants

17.6

3.0

Recreation Facilities*

0.6

0.1

Financial Institutions**

2

0.9

0.2

Total

* Other than those prohibited completely

**Restricted by the Virginia Legislature 
curtail their use; but it is doubtful that this restriction would redirect a significant portion of new investment away from growing regions or subregions.

The use of IDBs has evolved into a general subsidy for nearly all capital projects costing between $\$ 150,000$ and $\$ 10$ million. Total elimination of IDBs, as has been proposed, would be tantamount to imposing an investment tax on such new capital formation. Their primary benefits have been reduced capital costs for growing firms, industries, and regions which may have experienced difficulty in financing new investments at today's record high level of interest rates. These are the appropriate benefits that must be weighed against the costs of IDBs during future deliberations on their use, abuse, or elimination.

\section{FOOTNOTES}

1The terms Industrial Development Bond (IDB) and Industrial Revenue Bond (IRB) are interchangeable.

2Data for this study were compiled through a case-by-case review of bond documents maintained at each of the agencies in the region which issued IDBs between 1973 and 1982. The data set thus established is significantly richer in descriptive information than data maintained by public agencies which, as a rule, only compile statistics on number of issues and dollar volume. This original data therefore provides a unique opportunity to analyze the types of projects and firms which have benefited from the use of IDBs. A review of the existing literature revealed no comparable descriptive data sets.

3The Industrial Development and Revenue Bond Act of 1966, as amended, establishes Virginia State guidelines for the use of IDBs. Section 15.1-1374 (d) of the Virginia Code permits IDBs to be used to finance the following projects; medical, pollution control, industrial, parking or commercial facilities, as well as homes for the aged and facilities for private schools and colleges.

4Only 5 percent of the region's IDBs were public issues. National estimates of IDB use are based primarily on public issue records and therefore can seriously underestimate total national volume (CBO, p. 15).

oThe employment growth rates for 1973-82 were 52.3 percent, 30.0 percent, and 24.0 percent, respectively. (Virginia Employment Commission, Employment, Hours and Earnings.)

The other causal direction still exists, however, to the extent that the lower interest rates associated with IDBs lead to increased capital formation.

"With the use of general obligation IDBs, the community issuing the bond would essentially act as a "co-signer" on the loan. Although this is permitted in most states, localities avoid their use because of the risk and necessary public referendums involved.

8The ineffectiveness of subsidies to influence inter-regional location decisions is widely accepted (CBO, p. 48-50; Economic Review, p. 16). Opinion is more divided about their influence on intra-regional location decisions (Pascarella and Raymond, p. 77), but the CBO (p. 48-50) argues that even intra-regional influences are minimal.

${ }^{\circ}$ Virginia Employment Commission, Employment, Hours and Earnings. The largest city in the SMSA, Virginia Beach, was the 25th fastest growing city in the nation from 1972-1982 (Virginia Pilot, March 31, 1984).

10The data for IDB issues in the U.S. were obtained from the Flow of Funds Accounts published by the Federal Reserve System.

Data for public issues were obtained from the Public Securities Association, and private issue estimates were supplied by the Congressional Budget Office. The CBO readily admits that their estimates are likely to be quite low (CBO, p. 15).

${ }^{11}$ For example, the City of Norfolk now requires bond council opinions from independent attorneys representing the firms, the development authority, and the city councils thus increasing the necessary legal fees.

\section{REFERENCES}

Apilado, V. P., "An Appraisal of Industrial Aid Financing." Municipal Finance, March 1968, pp. 151-160.

Board of Governors of the Federal Reserve System, Flow of Funds Accounts.

Congressional Budget Office, Small Issue Industrial Revenue Bonds, Washington, D.C.: Government Printing Office, 1981.

Federal Reserve Bank of Atlanta, "Survey of Location Decisions in the South." Economic Review, June 1982, pp. 6-19.

Kopke, R. W., and R. F. Syran. "Tax Incentives: Their Impacts on Investment Decisions and Their Cost to the Treasury." The New England Economic Review, January/February 1978, pp. 19-32.

Laufenberg, David E. "Industrial Development Bonds: Some Aspects of the Current Controversy." Federal Reserve Bulletin, March 1982 , pp. $135-141$.

Luger, Michael I. "Federal Tax Incentives as Industrial and Urban Policy." In Sawyers and Tabb (eds.), Sunbelt/Snowbelt. New York: Oxford University Press, 1984.

Pascarella, Thomas A., and Richard D. Raymond. "Buying Bonds for Business: An Evaluation of the Industrial Revenue Bond Program." Urban Affairs Quarterly, September 1982, pp. 73-89.

Virginia Employment Commission. "Virginia Employment Hours and Earnings." Various issues. 